\title{
EFFICACY OF ESSENTIAL OILS FROM MEDICINAL PLANTS IN CONTROL OF THE HAIRY ROSE BEETLE, TROPINOTA SQUALIDA (SCOPOLI) AND THEIR COMPARATIVE TOXICITY TO THE HONEY BEE, APIS MELLIFERA L.
}

\author{
Mohammad S. Al-Alawi \\ Faculty of Agricultural Technology, Al-Balqa' Applied University, Assalt, 19117, Jordan
}

Received 2014-02-08; Revised 2014-02-15; Accepted 2014-03-18

\begin{abstract}
ABSTARCT
The insecticidal activity of essential plants oils against an important insect pest of fruit trees, the hairy rose beetle, was evaluated in topical and feeding applications in the laboratory. Essential oils that caused more than $50 \%$ mortality were further tested against the hairy rose beetle and the honey bee using different concentrations and their relative toxicities were evaluated. Results showed that eucalyptol and fir oils outperformed other tested oils and caused 72 and $64 \%$ mortality, respectively. These mortalities were not different from the application of the commercial insecticide, Deltamethrin. Moreover, eucalyptol and fir oils were more toxic to the hairy rose beetle than the dominant pollinator during fruit trees flowering, the honey bee. However, eucalyptol was relatively safer to the honey bees than fir oil. These findings indicate that eucalyptol might be applied during fruit trees bloom to control the hairy rose beetle even in the presence of honey bees if used for the crop pollination.
\end{abstract}

Keywords: Tropinota Squalida, Apis Mellifera, Eucalyptol, Mortality, LC $_{50}$

\section{INTRODUCTION}

The hairy rose beetle, Tropinota squalida (Scoploi) (Coleoptera: Scarabaeidae) is one of the major pests of fruit trees and ornamental plants. The adult insects oviposit in the soil where the hatched larvae feed on decaying organic matter. Pupation takes place in the soil in an oval chamber constructed from soil particles. At the end of the pupation period, the adults, ecdyse but remain in their chambers for the next year (Hussien et al., 2005). In the Mediterranean region, adult emergence from the soil occurs in late January and continues through the spring months (Hussien et al., 2005). After emergence, adults move to the host plants flowers for feeding and reproduction. The beetles feed on the reproductive parts of the flowers, mainly pollen and stamina (Toth et al., 2009). Severe economic damage results from the destruction of the flower's reproductive parts and lack of sufficient fruit set.
Control of the hairy rose beetle is difficult and depends on the application of insecticides. In addition to the known hazards of pesticides on humans and the environment, their application during plant flowering is restricted due to the abundance of pollinators foraging the plants for pollen and nectar such as honey bees (Schmera et al., 2004). Therefore, the development of new and ecofriendly control methods is essential for reducing the damage caused by the hairy rose beetle while preserving the pollinators.

Plants are regarded as biological factories that produce a different variety of chemicals collectively referred to as secondary metabolites (Kim et al., 2005). Secondary metabolites were considered a corner stone in natural plant defense against pest attack. Plant essential oils are one of the major groups of secondary metabolites that have been the focus of commercial development as natural insecticides. Some essential oils were used against many pests, particularly greenhouses, domestic 
as veterinary insects and diseases (Isman, 2006). Botanical pesticides including essentials oils are characterized by low mammalian toxicity, reduced effect on non-target organisms and short persistence in the environment (Isman, 2006; Georges et al., 2007) making them potentially preferable for incorporation in integrated pest management programs (Al-Alawi, 2013). Therefore, the current study evaluated the insecticidal activity of six essential plant oils for their toxicity against the hairy rose beetle and the honey bee, Apis mellifera which is abundant in fruit trees orchards during flowering. Evaluation of insecticidal activity is one of the primary steps in discovery and development of botanical insecticides. Developing botanical insecticides that are effective against the pest but safe for humans, pollinators and other useful organisms is crucial for sustainable pest management.

\section{MATERIALS AND METHODS}

\subsection{Plant Essential Oils and Insects}

Six plant essential oils were evaluated for their toxicity against the hairy rose beetle. They were cinnamon, eucalyptol, fir, pine, thyme and rosemary oils. The tested oils were supplied from the manufacturer (Sigma-Aldrich, EU) as pure oils with at least $95 \%$ purity.

Adults of the hairy rose beetle were collected from apple orchards in Ashoubak region located $220 \mathrm{~km}$ south of Amman. This region comprises the main apple growing area in Jordan. The collected beetles were kept in $2 \mathrm{~L}$. Glass jars covered with fine mesh for aeration until used in the bioassay. Honey bee collected Pollen grains mixed with $50 \% \mathrm{wt} / \mathrm{wt}$ sugar syrup were provided for the beetles for feeding. Honey bees were collected from hives maintained in the bee laboratory at Al-Balqa' Applied University. The honey bees were collected shortly before the bioassay trials and used immediately.

\subsection{Bioassay with Oils}

Groups of ten hairy rose beetle adults were randomly selected from the collected insects. Each group was randomly assigned to an oil treatment. The treatments involved testing six oils at a concentration of $10.0 \% \mathrm{wt} / \mathrm{wt}$ in sterile distilled water amended with $1.0 \%$ wt/wt dimethyl sulfoxide. The tests also included two controls: The insecticide, Deltamethrin as a positive control and sterile distilled water amended with $1.0 \%$ wt/wt dimethyl sulfoxide as a negative control. Before oils application, the groups of insects were placed in a refrigerator at $4^{\circ} \mathrm{C}$ for $10-12 \mathrm{~min}$. to anesthetize them during application. The anesthetized insects were then placed in sterile petri plates and sprayed topically with the corresponding oil using a potter spray tower (Burckard Scientific, UK). Control treatments were applied first and the tower was washed with sterile distilled water between applications to avoid any carryover effect. After treatment, the treated insects were left in the petri plates until the end of the anesthetized period to make sure that they did not die during application and were then placed in $250 \mathrm{~mL}$ transparent plastic cups covered with fine mesh. Honey bee collected Pollen grains mixed with $50 \% \mathrm{wt} / \mathrm{wt}$ sugar syrup were provided for the beetles for feeding. The cups containing the insects were then placed in a growth chamber at $24^{\circ} \mathrm{C}$ \pm 2 and a $16 \mathrm{~h}$. photoperiod. Numbers of dead hairy rose beetle adults were recorded daily for $4 \mathrm{~d}$. post application. A hairy rose beetle adult was considered dead if it did not move after probing with a fine hair brush. Another bioassay was carried out using feeding application instead of topical application. In the feeding bioassay, the insects were starved for $12 \mathrm{~h}$. then placed in the $250 \mathrm{~mL}$ transparent plastic cups supplied with oils were mixed with $10 \mathrm{~g}$ of the pollen and sugar syrup. Again, the insects were fed with the same oils and concentrations and incubated as above. For both topical and feeding bioassays, there were 5 replicate groups of insects each containing 10 adults for each oil as well as the controls.

Depending on the results from the previous bioassay, oils that caused more than $50 \%$ mortality were selected for further trials. The selected oils were eucalyptol and fir oils. The toxicity of these two oils was evaluated as above against the hairy rose beetle adults and the honey bee at four different concentrations. The concentrations were 5.0, 10, 15 and $20 \% \mathrm{wt} / \mathrm{wt}$. the mortality of both the hairy rose beetle and the honey was recorded $4 \mathrm{~d}$. post application. Again, a negative control consisting of sterile distilled water amended with $1.0 \% \mathrm{wt} / \mathrm{wt}$ dimethyl sulfoxide was included in the test. There were 5 replicate groups of insects each containing 10 adults for each oil/concentration combination.

\subsection{Statistical Analysis}

The assumptions of model for Analysis of Variance (ANOVA) were tested using PROC univariate, residual analysis. When assumptions were not met, the data were transformed. Percentage mortality of the hairy rose beetle adults were corrected using Abbotts formula (Abbott, 1925) then arcsine square-root transformed before subjecting to two way ANOVA (SAS, 2002). Means were separated using the Student-NewmanKeuls test (SNK) multiple range test. Lethal Time (LT50) and bioassay trials with oils at different concentrations were analyzed by Porbit analysis (SAS, 2002). The type I error rate was set at 0.05 level for all tests. Mortality data were back-transformed to their original scales for presentation in tables. 


\section{RESULTS}

Analysis of variances showed no interaction between the type of oil and the application method. However, significant differences were found due to oil type and the application method. For topical application, eucalyptol resulted in the highest mortality among the tested essential oils followed by fir oil (Table 1). Mortalities resulted from eucalyptol and fir oil were not significantly different from the mortality resulted from the application of the insecticide Deltamethrin. Thyme, rosemary, cinnamon and pine oils resulted in mortalities less than $50 \%$. These mortalities were significantly lower than those resulted from eucalyptol, fir oil and Deltamethrin. Thyme oil caused mortality of $40 \%$ which was significantly lower than the mortalities caused by eucalyptol and fir oil. However, mortality due to thyme oil was significantly higher than rosemary, cinnamon and pine oils (Table 1). For feeding application, all the oils as well as Deltamethrin resulted in mortalities less than $50 \%$. The highest mortality among oils was achieved by feeding the insects with fir oil followed by rosemary oil with no significant difference among them. Moreover, results showed significant difference in mortality of the hairy rose beetle due to application method for Deltamethrin, eucalyptol and fir oil but not for the rest of the tested oils (Table 1). In terms of speed of causing mortality which is expressed as the $\mathrm{LT}_{50}$ (Lethal Time to kill $50 \%$ of treated hairy rose beetles), no significant differences were found between the eucalyptoland fir oiltreatments. The $\mathrm{LT}_{50}$ for eucalyptol was $(1.3 \mathrm{~d})$ while for fir oil was (2.1 d) (Table 2).

Table 1. Effect of plant essential oils on the hairy rose beetle adults using topical and feeding applications

\begin{tabular}{lll} 
& Mean mortality percent \pm S.E. & \\
Tested material & - Topical application & Feeding application \\
\hline Deltamethrin & $82 * a+5.8$ & $48 * a .5$ \\
Eucalyptol & $72 * a \pm 5.9$ & $21 * \mathrm{bc} \pm 4.0$ \\
Fir oil & $64 * \mathrm{a} \pm 6.8$ & $41 * \mathrm{a} \pm 5.3$ \\
Thyme oil & $40 \mathrm{~b} \pm 7.1$ & $24 \mathrm{bc} \pm 4.2$ \\
Rosemary oil & $20 \mathrm{c} \pm 5.5$ & $33 \mathrm{ab} \pm 5.1$ \\
Cinnamon oil & $16 \mathrm{c} \pm 4.0$ & $14 \mathrm{c} \pm 3.7$ \\
Pine oil & $12 \mathrm{c} \pm 2.0$ & $18 \mathrm{c} \pm 6.1$ \\
\hline
\end{tabular}

Means within columns with different letters or between columns with asterisks are significantly different at 0.05 level using StudentNewman-Keuls test (SNK) multiple range test

Table 2. Lethal Time $\left(\mathrm{LT}_{50}\right)$ and lethal Concentration $\left(\mathrm{LC}_{50}\right)$ of hairy rose beetle adults treated with two essential oils at different concentrations

\begin{tabular}{|c|c|c|c|c|c|c|}
\hline \multirow[b]{2}{*}{ Oil } & \multicolumn{3}{|c|}{ Lethal time in days } & \multicolumn{3}{|c|}{ Lethal concentration } \\
\hline & $\mathrm{LT}_{50}$ & Lower CL & Upper CL & $\mathrm{LC}_{50}$ & Lower CL & Upper CL \\
\hline Eucalyptol & 1.3 & 0 & 1.8 & 7.2 & 6.0 & 8.3 \\
\hline Fir oil & 2.1 & 1 & 3.3 & 8.6 & 7.2 & 10.1 \\
\hline
\end{tabular}

Lethal Time $\left(\mathrm{LT}_{50}\right)$ and lethal Concentration $\left(\mathrm{LC}_{50}\right)$ with overlapping 95\% Confidence Limits $(\mathrm{CL})$ is not significantly different

Table 3. Lethal Concentration $\left(\mathrm{LC}_{50}\right)$ of honey bee adults treated with two essential oils at different concentrations

\begin{tabular}{lccc}
\hline Oil & Lethal concentration $\mathrm{LC}_{50}$ & Lower CL & Upper CL \\
\hline Eucalyptol & 18.2 & 14.5 & 33.8 \\
Fir oil & 14.0 & 11.8 & 17.8 \\
\hline
\end{tabular}

Lethal Time $\left(\mathrm{LT}_{50}\right)$ and lethal Concentration $\left(\mathrm{LC}_{50}\right)$ with overlapping 95\% Confidence Limits $(\mathrm{CL})$ is not significantly different

Table 4. Relative toxicity expressed as toxicity ratio between Lethal Concentrations $\left(\mathrm{LC}_{50}\right)$ of honey bees and hairy rose beetle

\begin{tabular}{|c|c|c|c|c|}
\hline & \multicolumn{2}{|l|}{ Eucalyptol } & \multicolumn{2}{|l|}{ Fir oil } \\
\hline & Hairy rose beetle & Honey bees & Hairy rose beetle & Honey bees \\
\hline Hairy rose beetle & 1.0 & 2.53 & 1.00 & 1.63 \\
\hline Honey bees & 0.4 & 1.00 & 0.61 & 1.00 \\
\hline
\end{tabular}

Relative toxicity is calculated by dividing the lethal concentration $\mathrm{LC}_{50}$ for hairy rose beetle or honey bees in the row by the $\mathrm{LC}_{50}$ in the column 
Based on the above results, eucalyptol and fir oils were selected for further evaluation. Concentration dependent experiments showed that the $\mathrm{LC}_{50}$ (lethal concentration to kill $50 \%$ of treated hairy rose beetles) were not significantly different between eucalyptol and fir oil treatments. The $\mathrm{LC}_{50}$ for eucalyptol was $7.2 \%$ while the $\mathrm{LC}_{50}$ for fir oil was $8.3 \%$ (Table 2).

The effect of eucalyptol and fir oil on honey beespresented in Table 3 showed that the $\mathrm{LC}_{50}$ for eucalyptol was $18.2 \%$ while the $\mathrm{LC}_{50}$ for fir oil was $14 \%$. No significant differences were found between the two oils in their effect on honey bees. By comparing the $\mathrm{LC}_{50}$ 's of eucalyptol against the hairy rose beetle and against honey bees, results showed that $\mathrm{LC}_{50}$ for eucalyptol against the hairy rose beetle is significantly lower than $\mathrm{LC}_{50}$ for honey bees. Similarly, the $\mathrm{LC}_{50}$ of fir oil against the hairy rose beetle is significantly lower than the $\mathrm{LC}_{50}$ of fir oil against honey bees. The relative toxicities for the hairy rose beetle and honey bees $\left(\mathrm{LC}_{50}\right.$ of honey bees divided by $\mathrm{LC}_{50}$ of hairy rose beetle) were 2.53 and 1.63 for eucalyptol and fir oil, respectively (Table 4).

\section{DISCUSSION}

Many medicinal plants contain essential oils that possess insecticidal and repellent activities against a range of insect pests (Isman, 2006) as well as animal pathogens (Mansour et al., 2014). The current study evaluated the insecticidal activity of six plant essential oils against the hairy rose beetle in an attempt to develop environmentally benign control methods. Eucalyptol and fir oil resulted in mortalities more the $50 \%$. The results also indicated that eucalyptol and fir oil were as effective as the tested insecticide. Deltamethrin is the insecticide used primarily for the control of the beetle in the apple growing region in Southern Jordan. The insecticidal activity of eucalyptol was previously demonstrated against several crop pests. Eucalyptol showed strong fumigant efficacy against greenhouse pests such as the spider mite, Tetranychus cinnabarinus (Attia et al., 2012). Additionally, eucalyptol was effective against the housefly, Musca domestica L. and the blowfly Chrysomya megacephala (F.) with an LD50 of 118 and $197 \mu \mathrm{g} / \mathrm{fly}$, respectively. Furthermore, eucalyptol reduced the adult longevity of both species (Sukontason et al., 2004). Very little is known about the toxicity of fir oil to insects and this might be the first record to show its efficacy against insect pests. The other tested oils showed mortality less than $20 \%$ indicating their ineffectiveness in killing the hairy rose beetle except for thyme oil which showed $40 \%$ mortality. Thyme oil insecticidal and repellent activities have been demonstrated for many Coleopteran pests such as Tribolium castaneum (Clemente et al., 2003), Sitophilus oryzae (Lee et al., 2001), Lasioderma serricorne (F.) (Hori, 2003). Because eucalyptol and fir oil resulted in the highest mortalities among the tested oils, they were selected for concentration response analysis. This analysis showed that eucalyptol killed $50 \%$ of the treated hairy rose beetles within 1.3 days $\left(\mathrm{LT}_{50}=1.3\right)$. The rapid action of the oil might suggest a neurotoxic mode of action. Some essential oils have shown to act by activation of octopaminergic receptors in stored product insect pests (Kostyukovsky et al., 2002). Further concentration response analysis showed that $50 \%$ of the beetles were killed at a concentration of $7.2 \%\left(\mathrm{LC}_{50}=7.2\right)$. Generally, the chemical composition of plant essential oils comprises complex mixtures of monoterpenes, phenols and sesquiterpenes. The major constituent of eucalyptolis the monoterpene 1,8-cineole which is known for its insecticidal activity (Isman, 2006; Rattan, 2010).

Current control of the hairy rose beetle in fruit trees orchards relies primarily on the application of chemical insecticides. Chemicals are harmful for pollinators such as honey bees which are abundant during the blooming period of the trees (Schmera et al., 2004). Although oils are generally regarded as ecofriendly pesticides, the development of a rationale insecticide against the hairy rose beetle should involve evaluation against the abundant pollinator during apple bloom, the honey bee. Therefore, the insecticidal effect of the two selected oils, eucalyptol and fir oil, against the honey bee was evaluated. The toxicity ratio of eucalyptol for the hairy rose beetle versus honey bees was (2.53). Therefore, eucalyptol is two and half folds more toxic to honey bees than to the hairy rose beetle. While, the toxicity ratio of fir oil the hairy rose beetle relative to honey bees was (1.63) indicating that fir oil is nearly 1.5 times more times toxic to the hairy rose beetle compared to honey. Therefore, eucalyptol might be regarded safer for honey bees compared to fir oil.

Essential oils from medicinal plants have been traditionally used as fragrances and as food additive. When used as crop protectants, essential oils compared to chemicals insecticides are regarded as safer and environmentally benign products. Most essential oils are mostly nontoxic to mammals, birds and fish, have limited persistence in fresh water and soil and pose no residue concerns (Isman, 2006). Therefore, essential oils might provide a viable alternative for harmful insecticides.

\section{CONCLUSION}

The current study demonstrated strong insecticidal activity of eucalyptol and fir oils against the hairy rose beetle. These essential plant oils were as toxic to the insect pest as the commercial insecticide Deltamethrin which is used by growers for the control of the insect. Eucalyptol 
was relatively safe to the dominant pollinator during pome and stone fruit bloom, the honey bees. Plant essential oils tested in the current study constitute an essential part of food flavoring and used as food additives in many parts of the world which. Insect control measures based on safe substances might be easily accepted and adopted by growers. Therefore, eucalyptol has the potential to be developed as a bio-rationale insecticide against the hairy rose beetle. Although the insecticidal activity of eucalyptol was clearly demonstrated in the current study, efficacy evaluation under field conditions is crucial before development of this essential oil as a botanical insecticide.

\section{ACKNOWLEDGEMENT}

The current research was funded by the Deanship of Scientific Research at Al-balqa' Applied University. The author thanks Prof. Mazen Ateyyat for providing some of the oils, Reem Abbasi for helping in the laboratory work, Sofian alhanbali for collection and handling of honey bees.

\section{REFERENCES}

Abbott, W.S., 1925. A method of computing the effectiveness of an insecticide. J. Econ. Entomol., 18: 265-267.

Al-Alawi, M., 2013. Acaricidal Activity of Medicinal Plants Against the Developmental Stages of the Two Spotted Spider Mite, Tetranychus urticae (Acari: Tetranychidae). Int. J. Agr. Res.

Attia, S., K.L. Grissa, Z.G. Ghrabi, A.C. Mailleux and G. Lognay et al., 2012. Acaricidal activity of 31 essential oils extracted from plants collected in Tunisia. J. Essential Oil Res., 24: 279-288. DOI:10.1080/10412905.2012.676777

Clemente, S., G. Mareggiani, A. Broussalis, V. Martino and G. Ferraro, 2003. Insecticidal effects of Lamiaceae species against stored products insects. Bol. San Veg. Plagas, 29: 421-426.

Georges, K., B. Jayaprakasam, S.S. Dalavoy and M.G. Nair, 2007. Pest-managing activities of plant extracts and anthraquinones from Cassianigricans from Burkina Faso. Bioresour. Technol., DOI: 10.1016/j.biortech.2007.02.049

Hori, M., 2003. Repellency of essential oils against the cigarette beetle, Lasiodermaserricorne (Fabricius) (Coleoptera: Anobiidae). Appl Entomol Zool, 38: 467-473. DOI: 10.1303/aez.2003.467

Hussien, H., N. Dimetry, Z. Zidan, R. Isshak and F. Sehnal, 2005. Effects of insect growth regulators on the hairy rose beetle, Tropinota squalida (Col., Scarabeidae). J. Appl. Entomol., 129: 142-148. DOI: 10.1111/j.1439-0418.2005.00891.x
Isman, M.B., 2006. Botanical insecticides, deterrents and repellents in modern agricultural and an increasingly regulated world. Ann. Rev. Entomol. 51: 45-56. DOI: 10.1146/annurev.ento.51.110104.151146

Kim, H.G., J.H. Jeon, M.K. Kim and H.S. Lee, 2005. Pharmacological ectsofasaron aldehyde isolated from Acorusgramineusrhizome. Food Sci. Biotech. 14: 685-688.

Kostyukovsky, M., A. Rafaeli, C. Gileadi, N. Demchenko and E. Shaaya, 2002. Activation of octopaminergic receptors by essential oil constituents isolated from aromatic plants: Possible mode of action against insect pests. Pest Manag. Sci., 58: 1101-6. DOI: 10.1002/ps.548

Lee, B.H., W.S. Choi, S.E. Lee and B.S. Park, 2001. Fumigant toxicity of essential oils and their constituent compounds towards the rice weevil, Sitophilus oryzae (L.). Crop Prot. 20: 317-320. DOI: 10.1016/S0261-2194(00)00158-7

Mansour, A.M.A., H.M. Zaki, N.A. Hassan and N.A.M. ElNashar, 2014. Phenotyping, virulence characteristics of Aeromonas species and the effects of essential plant oils as antimicrobial agents against pathogenic isolates from different sources. Am. J. Infect. Dis., 10: 21-35. DOI: 10.3844 /ajidsp.2014.21.35

Rattan, R., 2010. Mechanism of action of insecticidal secondary metabolites of plant origin. Crop Prot., 29: 913-920. DOI: 10.1016/j.cropro.2010.05.008

SAS, 2002. Institute SAS/STAT user's guide, version 9. SAS Institute, Cary

Schmera, D., M. Toth, M. Subchev, I. Sredkov and I. Szarukan et al., 2004. Importance of visual and chemical cues in the development of an attractant trap for Epicometis (Tropinota) hirta Poda (Coleoptera: Scarabaeidae). Crop Prot., 23: 939-944. DOI: 10.1016/j.cropro.2004.02.006

Sukontason, K.L., B. Noppawan, K. Sukontason and W. Choochote, 2004. Effects of eucalyptol on house fly (Diptera: Muscidae) and blow fly (Diptera: Calliphoridae). Revista do Instituto de Medicina Tropical de São Paulo, 46: 97-101. DOI: 10.1590/S0036-46652004000200008

Toth, M., J. Vuts, F. Difranco, R. Tabilio and B. Baric et al., 2009. Detection and Monitoring of Epicometi shirta Poda and Tropinota squalida Scop. with the Same Trap. Acta Phytopathol. Entomol. Hun., 44: 337-344. DOI: 10.1556/APhyt.44.2009.2.10 